\title{
ARCHITECTURE OF THE ANCIENT LIBYAN PALACES BETWEEN (RESTORATION AND REUSE) CASE STUDY (PALACES OF THE WESTERN MOUNTAIN REGION)
}

\author{
Dr. Mariam. M. Shibub \\ Assistant Professor. Architecture Department \\ Engineering Faculty- Tripoli University \\ Dr.mariamshibub@gmail.com
}

\begin{abstract}
Among the most important and largest ancient artifices having retained their form and structure in Libya stand the historical palaces, located in the country's ancient cities and serving as a sign of past Libyan architectural identity. It is vital that these palaces, indicators of the functions of ancient Libyan society, be preserved, developed and revived for use as historic buildings. The main objective of this research paper is to understand how the palaces were used and to uncover the most important dimensions of the architectural and philosophical implications of these palaces, including how the architecture reflects a philosophy that endeavored to meet the human needs of the people of Libya of that time. Furthermore, it will explore how these buildings can be restored, preserved, developed and re-functioned in accordance with knowledge of the characteristics of these structures and their previous functions, as well as consideration of the most appropriate functions for after their restoration. This paper tries to answer all these questions, using them as a guide to propose a general strategy for conservation and reuse based on principles mandated by Libya's General Directorate for the Development of Historic Cities.

In order to arrive at precise answers, this paper adopted the inductive and analytical descriptive method in collecting data from historical sources. The researcher conducted field visits, surveyed, examined archives and used field photography. The focus was on studying and analyzing the implicit philosophical dimensions in the design of these palaces and their correlation with Maslow's theory (1954) of the hierarchy of human needs. Based on the results, this research paper presents a set of ideas that can be used in the process of restoration and reuse of these palaces to meet general needs. This paper also recommends the need to provide technical support to civil associations that are working on the restoration and maintenance of these historic landmarks and study the possibility of taking advantage of the palaces as tourist museums and grain silos in the upper parts after maintenance and restoration.
\end{abstract}

Keywords: Architecture of palaces, historical buildings, implicit dimensions, restoration, reuse. 


\section{Introduction}

The term 'palace' has been used to describe many different types of buildings with different uses in western Libya. On mountain tops and specifically on the outskirts of the ancient city of Leptis Magna and in the regions of Mssalata and Tarhouna, the word 'palace' was written on a number of ancient Phoenician or Roman tombs, such as the Palace of the Duyrat, the Red Palace and the Abu Nasr Palace. The term 'palace' is also used to refer to buildings belonging to rich people or rulers, such as the Palace of Ben Talis in the region of Ceylon. These archaeological and historical buildings are so named as a result of their use in various jobs by people carrying those names. Sometimes, the names were indicative of shape or color, such as the Red Palace and the Palace of the Chocaf in the suburb of the Leptis Magna. In cities in the mountains, from Garyan, Yefran and Jadu, passing through Kabbao and Hamoud to Nalut and Wazen, the term 'palace' was used to refer to storehouses for agricultural products--mainly grains - such as wheat, barley, lentils and olive oil.

Notice the two pictures below on the right and the left showing the location of a palace at the top of a mountain and its shape from the outside as a fortress of solid walls. Also note the picture in the middle displaying rooms of the palace inside Figure (1). These palaces have the names of people, cities, villages, tribes or social structures, such as Al Haj Palace, Qasr-Bin Naran, Qasr-Yefran, Qasr-Kabau, Nalut Palace, Waazen Palace, Qasr-Al Hawamd and QasrAl Mujabrah. Most of them are similar in form and function and are similar in location and building materials used (Shukri Saeed 2009).
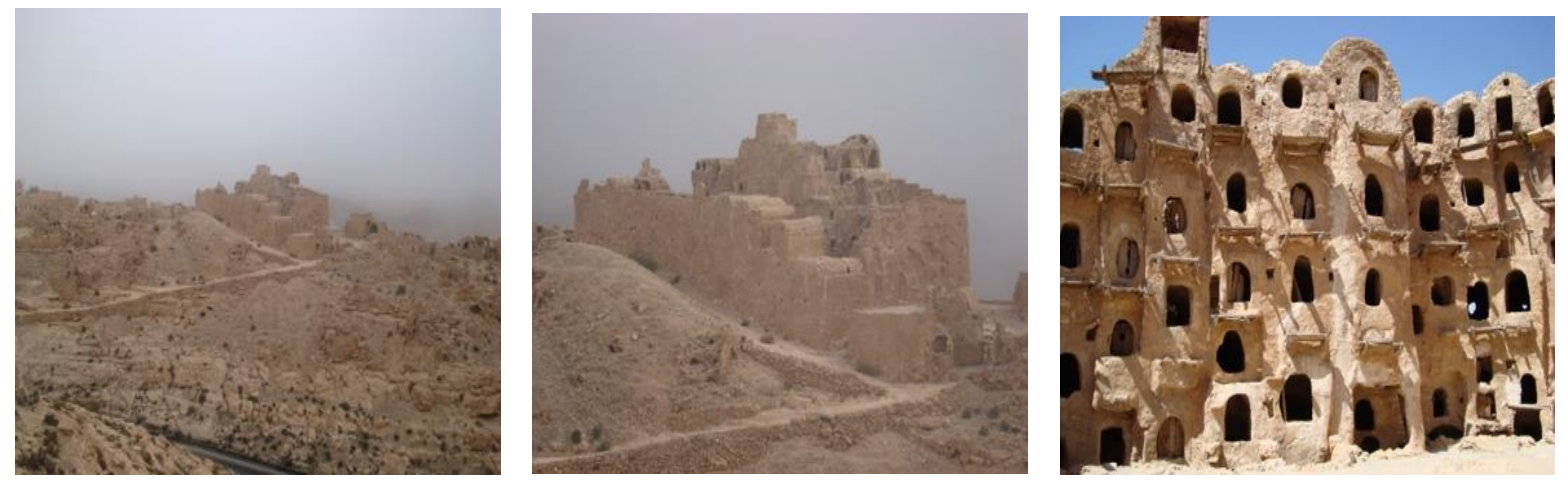

Figure (1): Nalut Palace

\section{Research Problem}

The research problem is lack of information about the implicit and philosophical dimensions and architectural specificity. Hence the idea of this paper is an attempt to study, understand and draw the dimensions reflected by these palaces. This is the reason for the architectural 
success and function of these buildings that remain as witnesses and architectural features adorning the western mountains.

\section{Research Objectives}

- To highlight the type of building and clarify the most important architectural features behind the success of these palaces and their permanence.

- Extract the most important implicit and philosophical architectural dimensions that these old palaces would have reflected in meeting the needs of the people.

- Understand the sustainable techniques and mechanisms these palaces used to work in harmony with nature and their environment.

To achieve these goals, many questions must be answered.

\section{Research Question}

1) How can these buildings and historical monuments be preserved?

2) How can they be restored, maintained, developed, reused and used?

A few sub-questions arise from the general questions:

1. What was the function of the Libyan palaces in the western mountain region and how did they function? How functional is it at present? What are the appropriate functions for reuse?

2. What were the most important influences on the building of the Libyan palaces in the western mountains?

3. What was the architectural philosophy reflected by the ancient Libyan palaces?

4. How did this philosophy reflect the levels of human needs of the people of Libya in the period in which they were built?

5. What are the design criteria that characterize the Libyan palaces in the Western Mountain Region?

\section{Methodology Used}

This paper adopts the inductive method of information collected while reviewing the literature published about the palaces in general and the Libyan palaces in particular. It also uses the descriptive analytical method and its various tools to collect information through questionnaires, field visits, surveillance and observation.

\section{Architecture of Palaces}

"The palace as a general concept is an architectural symbol that expresses the spirit of the state in particular and the civilization in general in a reflection of the nature of the relations between 
the human forces and the spiritual forces through the relationship between the individual and society" (Nayef Haddad, p.2, 2009). This policy has clearly influenced the construction and structure of the palace. The palace was formerly a king's residence or a government headquarters, a word derived from Palatine Hill in Rome. As a structure, the palace is quite different from the castle, which was originally a fortified dwelling ( $\mathrm{Ru}, \mathrm{J}$, Peng, H. 2015). "Palace architecture and political ideology are linked, however, by a dialectical relationship. Political ideology influences how palaces are built. And the architecture of a palace influences how we think of a ruler" (Arnold, F, 2017, P. xvi).

The idea of building palaces in the Arab countries emerged during the era of the third Caliph Uthman ben Affan. The resources of Arabs increased during that time period and birthed the concept of the Arabs leaving their old homes and replacing their simple role with prestigious palaces. The construction of these palaces coincided with an interest in choosing locations and the best building materials that would integrate well with the natural environment and social dimensions and provide comfort for its inhabitants. The design of the palace was characterized by its large and thick walls, which were shaped like fort walls, with towers in the corner and three additional round pillars on each side. The large walls were clearly marked in Islamic architecture, such as the palaces, mosques or so-called desert castles (Bartl \& Moaz, 2008).

The evolution of the construction of palaces has progressed and its functions have changed in different eras, such as during the Abbasid, Mamluk and Umayyad periods, and into the modern era (Omar Muhammad Shehat 2014). "The palace appears to have been used for a long time, first by the Aghlabids (876-909), then by the Fatimids (909-921), and finally by the Zirid dynasty (971-1057)" (Arnold, F, 2017, P.4).

\section{The Old Libyan Palaces}

Libya is characterized by hundreds of palaces in various western parts of the country and concentrated mostly in the western mountains, south of Tripoli, Tarhona and Bani-Walid. Most of these palaces date back to the 4th century AD, some to the 10th and 11th centuries. The most important features of the palaces of the 4th century AD are their features of refuge. They were built as fortresses on carefully chosen tall hills and highlands. These locations made the palaces difficult to enter and attack. The palaces in Libya are still proof of the splendor and elegance of the construction style of the era, displayed in their distinctive architecture, bright wall paintings and many inscriptions. The local Libyan architecture was influenced by, yet distinctive from, the Roman architecture that was prevalent in the Phoenician and Roman cities such as Oia, Leptis Magna and Sabratha. These palaces and castles in the western mountain region were an indication of the separation between the two civilizations and the survival of the local architecture at that time. 
The mountainous nature and the climate of the region had a significant impact on the construction of many towns and villages and palaces in the region of Tarhona, such as the Dugha Palace, Al-Banat Palace, and also Bou-Alarkan Palace in the town of Bani-Walid. In the Nafousa Mountains the environment also influenced construction, such as in seen in the old city of Kapaw, Druze Palace and Wazan Palace. These cities have become architectural landmarks over time through their distinctive architectural characteristics and difference from other cities in Libya. "The distinctive character of Libyan architecture is based on the solidity of the block and its dependence on it as an expressionist architectural element that merely emphasizes the innate population's awareness of the essence of the architectural art of feeling the value of the space occupied by the building and the confined space within its walls. The Libyan palaces of different styles created by the hands of the artistes of the construction of the Libyan evidence of the sense of the value of mass and its form and expressive capacity "(Riyadh Prince, 2000, P1).

The most important characteristic of the great Libyan palaces overlooking the highest peaks of the Nafousa Mountains is their high outer walls with no windows opening to the outside; all windows open to the inner corridors and courtyards. The preferred location for building habitations was a very high elevation. This is reflected in the consistent choice of suitable sites to build these palaces. The people of these cities chose sites with high elevations that overlooked the plains from three sides with the fourth side connected to the other mountains in the range and serving as a protective boundary. They quarried building materials from the mountains themselves to make the palaces an integral part of the mountain. In addition, the houses were built between the palaces and the areas overlooking the valleys in order to protect the villages from all sides. For each palace, the only road leading to the village was controlled by its path through the palace, with a large rock at its entrance.

The Nafousa Mountains in western Libya was not influenced by European civilization, but rather displayed the dominant local architecture, until the Islamic conquest, which had a great impact on all aspects of life in general, and Libyan architecture in particular. In the past, and even now, the Nafousa mountains was the most influential of Libyan schools of thought in local architecture in the second half of the $20^{\text {th }}$ century. According to the Italian writer $(\mathrm{G}$ Rossi 1933), there are about fifty palaces in the area of Harraba and the balance are in the western part of the region. Some of them have been destroyed and the rest are in a good condition. Most of the palaces in this area were used for storage purposes, such as for grain, other food stuffs and agricultural products, and weapons.

The palaces of the Nafousa mountain were not built for continual habitation but were food storage areas and served as a central storage bank for the city. Palaces were divided into several small rooms, with each room assigned to a specific family to store its grain, oil and figs. The Libyans developed storage methods and tools to be able to save these items for long periods of time. 
One of the most striking examples of these palaces is the Waazen Palace. Located at the western end of the Nafousa Mountains, it occupies a position at the top of the mountain. Waazen Palace is characterized by its unadorned walls with many slots and four corners and its open oval-shaped courtyard; it is accessed through the ladder. In addition, there are high compartments around the palace where the grain was stored. These compartments, made of olive wood and isolated from each other, were used as stairs.

Nalut Palace is one of the most important palaces built in its time. This palace was built in the 7 th century $\mathrm{AD}$ in a location overlooking a valley known as the city of Nalut. It is a huge circular building; the number of floors ranges from 3 to 6 floors. It has about 400 rooms, which are distributed geometrically in a manner consistent with its function and space, and fulfilling its purpose. The rooms of the palace are separated by corridors on each floor and a staircase is used as a connection between these floors. These rooms were used for storage of grain. The rooms are the main element in the construction of the palace. The most important influences here are the various economic situations of the owner of these rooms; this determined the different types of rooms and their sizes. The rooms were often grouped according to joint ownership by tribes and families, and this is a clear indication of the social cohesion between families and tribes. Natural stones were the main source of building material. The ceilings of these rooms were usually in the form of cellars to carry the weight of the upper rooms. The rooms were covered with plaster and lime to prevent insects and lichens. The dimensions of the room are usually not less than $20 \mathrm{~cm}$ and the height is not less than the height of the man and the doors are made of palm trunks with dimensions of $50 \mathrm{~cm}-70 \mathrm{~cm}$. The ventilation of the rooms comes from the door opening and some narrow external slots. The rooms are divided on the inside by some of cavities (Al-Khawabi) to the interior and to the exterior as well as the upper and lower parts. These cavities are sealed by plaster and used to store oil. The granaries are also used for storage of wheat, barley, dry figs and dates. These basins are located in the upper part of the room. The Nalut Palace has been reconstructed three times with an increase in the number of rooms. The builders tried to enlarge the size of palace's rooms during the reconstruction, but the people refused the idea so that they could protect its architectural and cultural heritage. Important examples of similar villages are near the town of Nalut. These include Al-Daruj Palace village, the village of Nalut Palace, the village of Duqaija, and the village of the Palace of the Thirds.

Al Haj Palace is another model of the Libyan palaces distinguished by its form and design and in harmony with the nature of the land and the culture of the population. The Hajj Palace consists of a hundred and fourteen rooms used for storage. This palace was an economic institution that was funded, maintained and paid the salary of its employees from its income. The work and salary were in proportion to the harvest stored there.

Al-Asabah Palace, which is one of the most important palaces in the area of Al-Asabah, was built in the circular style of the storage palaces. The palace is a large, old stone building, and 
despite its relative size, it was built in a primitive style. It consists of rooms and vaults. The multiple rooms were used for long-term grain preservation and storage, while the basements used to store olive oil (Shukri Said Qatos 2009).

\section{The Description}

The old palaces of the western mountains (Nalut and Kabao) are distinguished by their height and fortification, built of small natural stones and primitive bonding materials such as clay, gypsum and lime. Thick outer walls tend inward as their height increases and are used for grain storage Figure (2). These palaces have one entrance, often rich in ornamentation and writing. These palaces have been modified over time to fit their function. They are made up of dozens of contiguous storage units, built one after the other, whether horizontally or vertically for several floors, sometimes more than six floors. The height of the storage unit rises to a human height or slightly lower, with a width ranging from two centimeters to one hundred and seventy centimeters, and a depth not usually more than six meters.

These storage rooms are divided on the inside to form basins for wheat and for barley. Oil is often stored in large pitchers of pottery installed in the walls; these pitchers increase in number according to need and size of the season's oil harvest. Access to the store is provided by an entrance in the shape of a small slot sufficient for a person to enter either crouched or standing. Stores located on the upper floors are accessed by stairs of stone, olive or palm trunk. In addition to that, in front of each entrance there is a break which provides a place wide enough to seat a person. This is used when the stored materials are inserted and removed after they are finished. The store is closed by a thick door made of polished palm trunks or olive stalks.
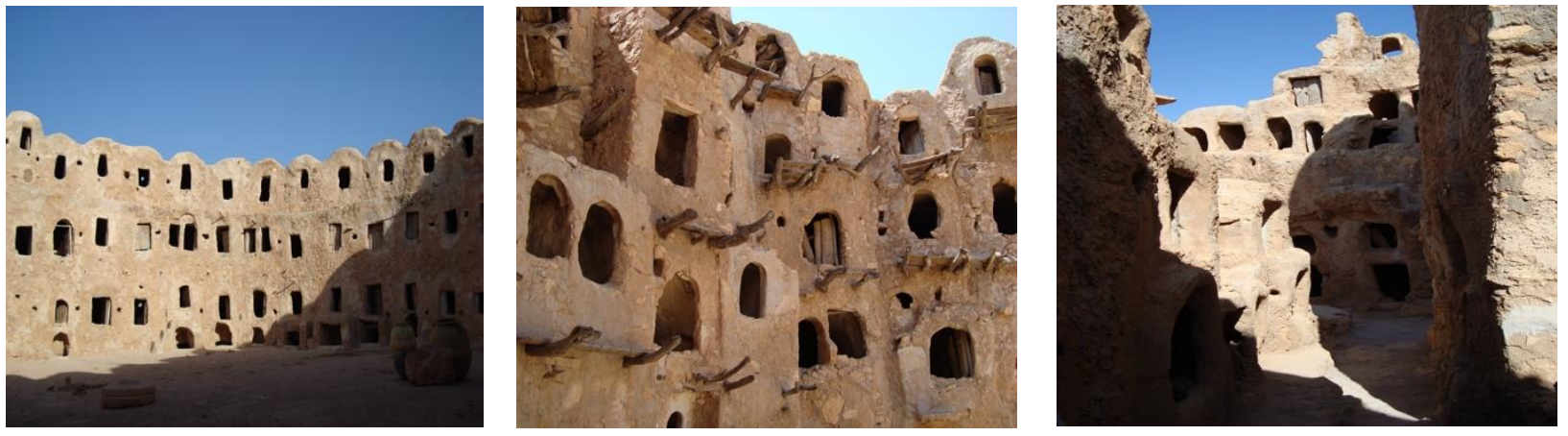

Figure (2): Storage Rooms in Nalut Palace

The palaces in the western mountain region have irregular, semi-circular shapes characterized by their large size, remarkable height and solid walls. All these features, such as the shape of small natural stones, their size and the light brown color, the color of the dark gray bonding 
material and its thickness (which covers part of the stones), gives the palaces the natural color of the mountain and makes them a homogeneous composition with nature. These palaces are born of nature and not strange or extraneous. The internal shape of the palaces is full of vitality; the irregular primitive construction and the small slots irregularly distributed over each other like the pigeon towers, not governed by a scale, give a sense of natural organic architecture. This architectural philosophy is confirmed by the random wrinkles in the walls, that give varying shades of intensity, and fluctuate with the change of shadow movement. This sensation is integrated with the images of the bumps of stairs and small rests, which are not governed by a scale or system.

\section{Functional Technical Criteria for Palaces as Stores for Foodstuffs}

The General Organization for Supply Commodities (GPC) rules specify the conditions that must be met in the warehouses used to store foodstuffs in the following technical points:

1. Maintain low and constant storage temperature.

2. Keep the storage space dry and prevent moisture from reaching the stored material.

3. Ventilate and allow for air regeneration while blocking or preventing sunlight.

4. Prevent the infestation of insects and rodents to the stored materials.

5. Secure the place and protect it from tampering or theft.

Various modern techniques are used in the storage system of feed stocks, especially grain, for example cooling systems, mechanical ventilation, moisture absorbing materials, and other insect repellents. In addition to the use of modern sterilization methods, the philosophical and implicit dimensions in the design of the storage unit in the palaces of the western mountains reflect a primitive system that is successful in achieving these storage requirements. The external temperature varies dramatically between night, day, summer and winter; it may differ more than 13 degrees Celsius between night and day and more than 31 degrees Celsius between summer and winter. However, the temperature and humidity within the storage unit are stable or fixed.

\section{The Design Criteria That Characterize the Storage Unit Are:}

- Thick external walls, with a thickness of more than seventy centimeters at the base.

- Specific shapes, with rectangular storage units linked horizontally in the form of closed circles, and each one covering the other vertically in the form of multiple floors. This reduces the proportion of space exposed to the sun.

- Upper units covered with thick layers of trunks, twigs and soil, enough to provide the required thermal insulation.

- Building materials used with a good thermal insulation coefficient. 
- Small size of the slots, with sufficiency of one very small slot at the opening of the entrance to keep the air inside and to prevent the sudden entry of large quantities external air.

- Suitable size of the storage volume for the stored material.

- Orientation of the building to the east in most cases, and adoption of only one entrance to protect it from the cold north wind and warm south wind.

- Internal courtyard of the building and the presence of the entry hole in the appropriate size to give the building a slow ventilation system that regulates the temperature inside.

- Lime coating of the storage unit from the inside to give appropriate lighting to the storage area. The lime reflects the indirect light falling through the opening of the entrance and gives proper light to the inside, while also preventing the presence of insects.

- Thickness and height of the palace and the presence of a single entrance tightly fitted with a door of thick palm trunks. This provide security and safety and protection for the storage unit.

- Use of clay and burned gypsum which helps to absorb moisture resulting from the winter after it loses any moisture during the summer and high temperature.

From these features we can deduce many of the implicit and philosophical dimensions that have led to the architecture used in these palaces:

- Functionality

- Security

- Social affiliation

- Technical dimension

- Religious considerations

- Climate and environmental suitability

- Value dimension

These are the values that Maslow focused on in his 1954 theory, which defines dimensions as the incentives that motivate a person to do what he actually wants to do in his environment. Whether it was a natural act or a result of a sense of visible or invisible, permanent or temporary feeling, Maslow divided these incentives into two: intrinsic and extrinsic. In architecture we see extrinsic motivators as various elements such as climate, building materials, site factors, etc. Intrinsic motivators are related to social interaction: participation, the attributes, customs inherited for coexistence and living. These intrinsic and extrinsic incentives are then classified into the needs of life, such as hunger, thirst, shelter, etc., and the need for safety, the need for belonging, self-esteem, ambition, knowledge and art (Abraham Maslow's hierarchy of needs, 2019). 
It is evident here that these implicit dimensions are directly reflected in the strategies of building the grain palaces in the western mountain region. The following table, a result of this study, shows the existence of these implicit philosophical dimensions and the elements that reflect the fulfillment of these dimensions in these palaces.

\section{Results}

This table was derived from a study of a sample of three palaces, selected from three different places in location and social structure, namely: Nalut Palace, Al Hawamd Palace and Kapaw Palace.

Table (1): The Dimensions Reflected by the Palace Architecture.

\begin{tabular}{|c|c|c|c|c|c|}
\hline \multirow[b]{2}{*}{ Dimensions } & \multirow[b]{2}{*}{ Response } & \multicolumn{3}{|c|}{ Palaces } & \multirow[b]{2}{*}{ Repetition } \\
\hline & & Nalut & $\begin{array}{c}\text { Al } \\
\text { Hawamd }\end{array}$ & Kapaw & \\
\hline \multirow{4}{*}{ Function } & Storage & - & - & - & $100 \%$ \\
\hline & Stairs and restrooms & - & - & - & $100 \%$ \\
\hline & Internal corridors & - & - & - & $100 \%$ \\
\hline & Arches and slots & - & - & - & $100 \%$ \\
\hline \multirow{4}{*}{ Security } & Thick solid walls & 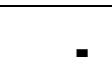 & 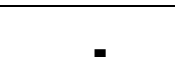 & . & $100 \%$ \\
\hline & Wall height and its rise & $\square$ & $\square$ & 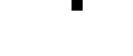 & $100 \%$ \\
\hline & Thickness of doors & - & - & - & $100 \%$ \\
\hline & One entrance & - & - & - & $100 \%$ \\
\hline \multirow{3}{*}{ Affiliation } & One place & $\cdot$ & - & - & $100 \%$ \\
\hline & Neighbor & $\cdot$ & - & - & $100 \%$ \\
\hline & Participation & - & - & - & $100 \%$ \\
\hline \multirow{4}{*}{ Art } & Writing & - & - & - & $100 \%$ \\
\hline & Inscriptions & - & - & - & $66 \%$ \\
\hline & Decorations & - & - & - & $66 \%$ \\
\hline & Color & $\cdot$ & - & - & $100 \%$ \\
\hline \multirow{2}{*}{ Spiritual } & Basmaalah & $\cdot$ & - & - & $100 \%$ \\
\hline & Quranic verses & - & - & - & $100 \%$ \\
\hline \multirow{4}{*}{ Environment } & Building materials & $\cdot$ & - & - & $100 \%$ \\
\hline & Site & $\cdot$ & - & - & $100 \%$ \\
\hline & Mountain & - & - & - & $100 \%$ \\
\hline & Fields & - & - & - & $100 \%$ \\
\hline \multirow{5}{*}{ The climate } & Internal basements & - & - & - & $100 \%$ \\
\hline & Directing the building & - & - & - & $100 \%$ \\
\hline & Shadows & - & - & - & $100 \%$ \\
\hline & $\begin{array}{l}\text { Protection from rain and } \\
\text { wind }\end{array}$ & - & - & - & $100 \%$ \\
\hline & Moisture and heat & - & - & - & $100 \%$ \\
\hline
\end{tabular}


The elements of the response to the stimulus cover more than one dimension at the same time, and Table (2) shows the dimensions covered by each element.

Table (2): The Dimensions Covered by Each Item.

\begin{tabular}{|c|c|c|c|c|c|}
\hline \multirow[b]{2}{*}{ Elements } & \multirow[b]{2}{*}{ Dimensions } & \multicolumn{3}{|c|}{ Palaces } & \multirow[b]{2}{*}{ Repetition } \\
\hline & & Nalut & $\begin{array}{c}\text { Al } \\
\text { Hawamd }\end{array}$ & Kapaw & \\
\hline Entrance & $\begin{array}{c}\text { Artistic, Security, } \\
\text { Environmental /Climate }\end{array}$ & - & - & - & $100 \%$ \\
\hline $\begin{array}{c}\text { The internal } \\
\text { courtyard }\end{array}$ & $\begin{array}{c}\text { Environmental/ Climate, } \\
\text { Functionality }\end{array}$ & - & - & - & $100 \%$ \\
\hline Stairs & Security, Functionality & - & - & - & $100 \%$ \\
\hline The doors & Security, Functionality & - & - & - & $100 \%$ \\
\hline The slots & $\begin{array}{l}\text { Functionality, Security, } \\
\text { Environmental/ Climate }\end{array}$ & - & - & - & $100 \%$ \\
\hline Building materials & $\begin{array}{c}\text { Environmental/ Climate, } \\
\text { Security }\end{array}$ & - & - & - & $100 \%$ \\
\hline Walls & $\begin{array}{c}\text { Environmental/ Climate, } \\
\text { Security }\end{array}$ & - & - & - & $100 \%$ \\
\hline The color & Environmental/ Climate & - & - & - & $100 \%$ \\
\hline Writing & Spiritual, Artistic, Belonging & - & - & - & $66 \%$ \\
\hline Inscriptions & Spiritual, Artistic, Belonging & - & - & - & $66 \%$ \\
\hline Decorations & Spiritual, Artistic, Belonging & - & - & - & $66 \%$ \\
\hline Site & $\begin{array}{c}\text { Function, Security, } \\
\text { Environmental/Climate, } \\
\text { Affiliation }\end{array}$ & - & & - & $100 \%$ \\
\hline
\end{tabular}

\section{Discussion}

Note from these tables that they carry many elements that can be classified into two parts. The first part is architectural elements, such as entrance, doors, slots, interior courtyard walls, stairs, building materials and location. And the second part is dimensions, such as the cultural or artistic elements of color decorations, inscriptions and writing ...etc. If we review the implicit dimensions of the two categories, architectural elements reflect the dimensions of function, security, climate, environment and art which is reflected in the following percentages: $100 \%$ function, $100 \%$ security, climate and environment $100 \%$. While the cultural and artistic elements reflect the spiritual dimensions and belonging by $100 \%$ and the art dimension by $66 \%$. 
This illustrates the implicit and philosophical dimensions reflected in the architecture of palaces in Libya and the need to preserve them as historic, cultural and social landmarks of this important period of life for the Libyan people.

The question that now arises is, "How can these historical landmarks be preserved, restored, developed and used?"

In the scope of this article we present a few general ideas that may be used as a springboard for further study and work. Firstly, attention should be given to the local NGOs that aim to restore and maintain historical buildings in the cities of Libya by spreading awareness and increasing interest in heritage. There are civil societies in Ghadames, Nalut and Kapaw. These associations are active in maintaining the historic old cities and palaces of these towns and have used the same traditional construction materials previously used in construction: clay, stone, lime, gypsum, hay, palm trees and olives. They have gone a long way in restoring and reusing large parts of these palaces in those towns. Supporting these associations and providing them with technical expertise and materials and encouraging them will play a large role in increasing their activity and contributing to the restoration and protection. When preservation and restoration activities are localized and are part of the inhabitants' activity in the region, this contributes more effectively to the preservation and management of these landmarks.

We also recommend the use of the most durable and long-lasting structural materials such as colored cement, plaster and wood processing to protect and prolong the life of the palaces.

Lastly, these landmarks can be preserved by re-using the palaces as tourist attractions, resulting in economic recovery and bringing attention to the needs of the population of the regions that have these types of palaces. It is suggested in this context to use the ground and basement floors as popular museums, accommodations for tourists or for physical treatments or exercises like yoga or physiotherapy which need isolation and exclusivity. As for the upper floors, it is proposed to study the use of these as silos for grain after making the necessary modifications. They can be opened vertically to establish some traditional food industries such as grain mills.
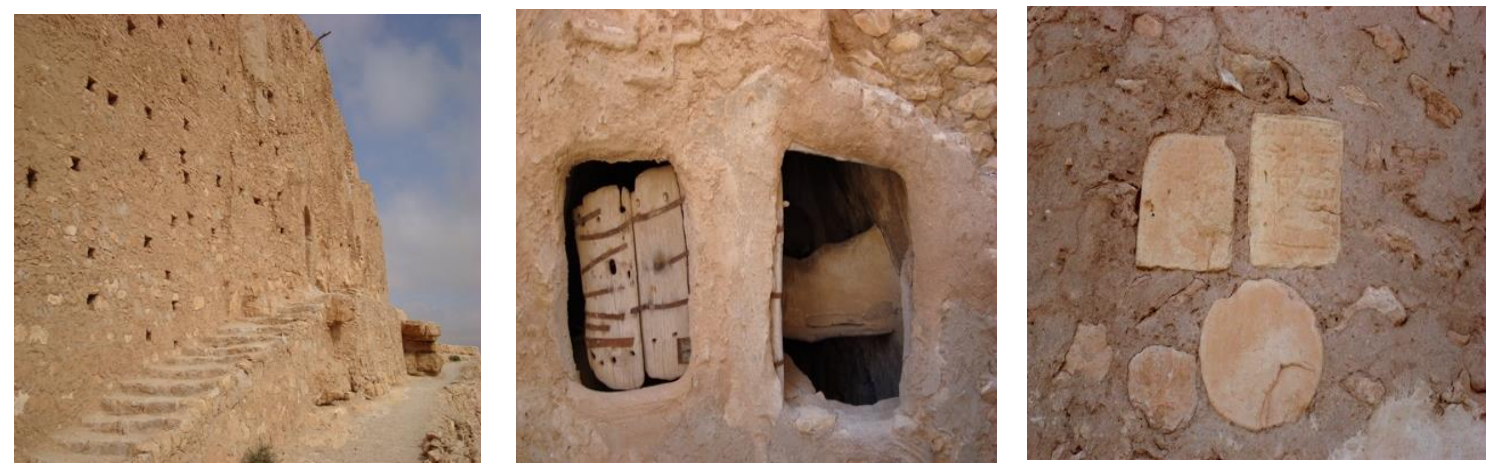

Figure (3): Entrance to Nalut Palace and the Surrounding Building 

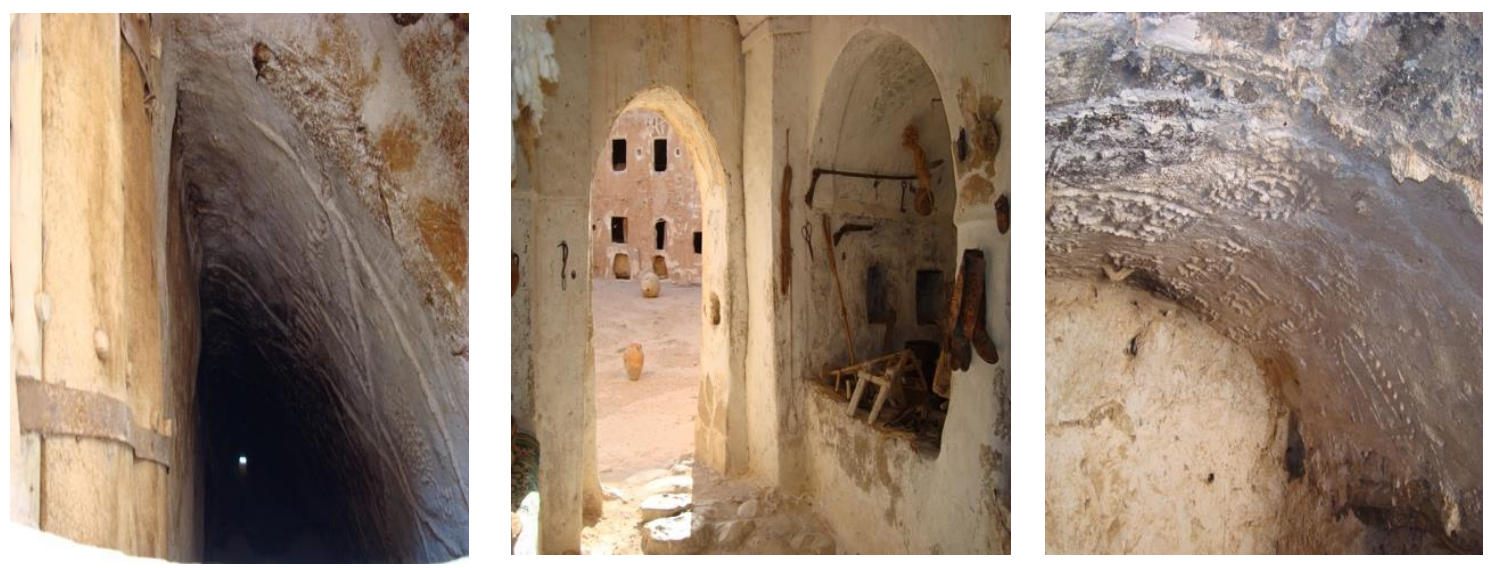

Figure (4): Inscriptions and Decorations

\section{Conclusion}

The elements of the palaces in the historical cities confirm exactly what was stated in Maslow's theory of the dimensions or incentives that drive humans' actions or events. The palaces in the cities and mountain villages reflect great understanding of and intelligent handling of climatic conditions. The properties of the used building materials and the skill of the Libyan builders and their interest in re-function of the architectural spaces of the grain palaces had a great impact in the service of career and security needs. It also reflects the social affiliation, social cohesion, and the close living standards of the users of the storage units in these palaces, and the weakness of the elements that may reflect philosophical implications such as the dimensions of self-esteem or self-love. The restoration and maintenance works carried out by the associations and the civil sector have had a great impact in preserving these heritage landmarks. Therefore, any strategies adopted must be focused on identifying or determining the uses of these palaces and supporting the NGOs that aim to restore and maintain historical buildings and give attention to them. It is also imperative that study is conducted regarding the possibility of benefiting from the palaces as tourist museums or activity centers that serve tourist purposes in the lower parts and grain silos in the upper parts after rehabilitation.

\section{References}

- Arnold, F (2017). Islamic Palace Architecture in Western Mediterranean History. Oxford University.

- Abraham Maslow's hierarchy of needs https://www.simplypsychology.org/maslow.html (data of access is 6/6/2019). 
- Bartl, K \& Moaz, A (2008). Residences, castles, Settlement: transformation processes from Late antiquity to early Islam in Bilad al-Sham- Proceedings of the international conference held at Damascus, 5-9 November 2006.

- Haddad Naiif. (2009). Architecture of the Palaces of Alami in Badia Al Sham: An Analytical Study on Privacy. Emirates Journal of Engineering Research. 14 (1) 1-8. p.2.

- $\quad$ Ru, J, Peng, H (2015). Palace Architecture: Imperial Palaces of the Last Dynasty (Library of Ancient Chinese Architecture). CN Times Beijing Media Time United Publishing Company limited.

- Peng, H. Ru, J (1998). Palace Architecture (Ancient Chinese Architecture). Springer Vienna.

- Omar Mohamed Shehat. (2014). History of our palaces in Islamic architecture, number 11.

- Shukri Saeed Al Qattous (2009). Architectural and architectural features of Nalut. Journal of inheritance.

- Mr. Abdelaziz Salem (1981). Mosques and palaces in Andalusia. Recently Published

- Riyadh Prince (2000). Historical and architectural views in the Libyan arts and architecture. Life Magazine. 